\begin{tabular}{|l|l|l||}
\hline \multicolumn{2}{|c|}{ PublisherInfo } \\
\hline \hline PublisherName & $:$ & BioMed Central \\
\hline \hline PublisherLocation & $:$ & London \\
\hline \hline PublisherImprintName & $:$ & BioMed Central \\
\hline \hline
\end{tabular}

\title{
A validated delirium instrument for the ICU
}

\begin{tabular}{|l|l|l||}
\hline \multicolumn{3}{|c||}{ ArticleInfo } \\
\hline \hline ArticleID & $:$ & 4325 \\
\hline \hline ArticleDOI & $:$ & $10.1186 /$ ccf-2002-75550 \\
\hline \hline ArticleCitationID & $:$ & 75550 \\
\hline \hline ArticleSequenceNumber & $:$ & 25 \\
\hline \hline ArticleCategory & $:$ & Paper Report \\
\hline \hline ArticleFirstPage & $:$ & 1 \\
\hline \hline ArticleLastPage & $:$ & 3 \\
\hline \hline & & RegistrationDate $: 2002-2-8$ \\
ArticleHistory & $:$ & Received \\
& $:$ Accepted 2002-2-8 \\
\hline ArticleCopyright & $:$ 2002-2-11 \\
\hline \hline ArticleGrants & $:$ & Biomed Central Ltd2002 \\
\hline \hline
\end{tabular}




\begin{tabular}{|l|l|l|}
\hline ArticleContext & $:$ & 1305466 \\
\hline
\end{tabular}

Richard Venn, Aff1

Aff1 Worthing Hospital, UK

\section{Keywords}

delirium, mechanical ventilation, monitoring

\section{Context}

The incidence of delirium has been difficult to define in the ICU since no validated simple delirium assessment instrument exists. Consequently identifying risk factors for delirium in the ICU in an attempt to develop preventative strategies has proved difficult. This study validates the Confusion Assessment Method for ICU patients (CAM-ICU) and determines the incidence of delirium in the ICU.

\section{Significant findings}

Delirium occurred in $83 \%$ of patients during their ICU stay for a mean of 2.4 days. Two ICU nurses using the CAM-ICU had sensitivities of $100 \%$ and $93 \%$, and specificities of $98 \%$ and $100 \%$ for the diagnosis of delirium when compared with assessments by delirium experts. Duration of CAM-ICU assessments was two (mean) minutes.

\section{Comments}

This study has validated the CAM-ICU delirium assessment score, which appears to be a relatively simple and quick assessment to perform in the ICU. Subgroup analysis shows good sensitivity and specificity for this test in those patients expected to be a sedation challenge; the elderly, those with dementia, and those with the highest severity of illness. It also appears that the incidence of delirium is much higher than previously reported. In the future we will be able to identify those patients at risk of delirium and change sedation practice to prevent its occurrence. 


\section{Methods}

Prospective cohort study over 6 month period involving 111 mechanically ventilated patients in the $\mathrm{ICU}$, comparison of nurse led CAM-ICU delirium assessments with those by delirium experts

\section{References}

1. Ely EW, Inouye SK, Bernard GR, Gordon S, Francis J, May L, Truman B, Speroff T, Gautam S, Margolin R, Hart RP, Dittus R: Delirium in mechanically ventilated patients: validity and reliability of the confusion assessment method for the intensive care unit. JAMA. 2001, 286: 2703-2710.

This PDF file was created after publication. 